\title{
Screening of Silk Fibroin as a Stabilizer for Freeze Drying of Thermolabile Drug
}

\author{
Pooja Gajanan Mirajkar, Ashok Ananda Hajare* \\ Department of Pharmaceutics, Bharati Vidyapeeth College of Pharmacy, Kolhapur, Maharashtra, INDIA.
}

\begin{abstract}
Aim: In the present research work an attempt is made to investigate use of silk fibroin as a stabilizer for model thermolabile drug Tenofovir Alafinamide Fumarate (TAF). Materials and Methods: On the basis of literature reviewed various lyophilized formulations of TAF using silk fibroin as a stabilizer were prepared. Lyophilized formulations were optimized by analyzing for \% drug content, \% moisture retention and appearance of lyophilizate and further investigated by using modern techniques such FT-IR, XRD and DSC. Formulations were tested to confirm suitability of silk fibroin to stabilize TAF during lyophilization. Initially for achieving desirable product features the fibroin concentration was optimized. The optimized concentration of fibroin was compared with commonly used cryoprotectants such as mannitol and sucrose. The process efficiency of fibroin as cryoprotectant was compared using product features. Results: Product features and stabilization efficiency of fibroin was lower than mannitol where as it was better than sucrose. The short term stability study retained drug to desired strength indicating lyophilized products stability over the period of a month. Thus it can be concluded that silk fibroin could be successfully used to stabilize theromosensitive therapeutics. In comparison fibroin seems to stabilize labile drugs efficiently reducing production cost and at lower toxicity risk. Thus, natural silk fibroin is a promising excipient to be used as a stabilizer due of its cryopreserving properties.
\end{abstract}

Key words: Silk fibroin, Stabilizer, Tenofovir Alafinamide Fumarate, Freeze drying.

\section{INTRODUCTION}

As we know pharmacy is the science and technique of preparing and dispensing drugs and aims to ensure the safe and effective use of pharmaceutical drugs. Even though, we still face some problems such as instability, solubility, degradation of drugs etc. Cells, proteins, enzymes, endotoxins, microorganisms and some of the drugs are very sensitive to processing and storage temperature losing its integrity. Being unstable it must be stored at lowest temperature $\left(2-8^{\circ} \mathrm{C}\right)$ which needs cold chain facilities.

The storage and preservation of these thermolabile entities is a critical issue in their successful use. Freeze drying (FD, lyophilization) is a technique of converting material into dry form at temperature below freezing point enhancing stability. The low operating temperature reduces the damages that can occur with traditional drying processes and guarantees stability and optimal use conditions until the expiration date. FD is a method of removing water by sublimation of ice crystals from frozen material. Suitable parameters of process application allow us to obtain best quality products compared to products dried with traditional methods. In pharmaceutical field lyophilization has become important subject to ongoing development and its expansion. ${ }^{1}$

Freeze drying of thermolabile substances needs some excipients to be used as a cryoprotectants or stabilizers. ${ }^{2}$ It protects the labile materials from low temperature damages during freezing while provide protection against the stresses that occurs
Submission Date: 15-08-2018; Revision Date: 10-01-2019; Accepted Date: 21-02-2019.

DOI: 10.5530/ijper.53.2s.66 Correspondence: Ashok Hajare, Department of Pharmaceutics, Bharati Vidyapeeth College of Pharmacy, Kolhapur-416013, Maharashtra, INDIA. Phone: +919763226302 E-mail: pmirajkar415@gmail. com

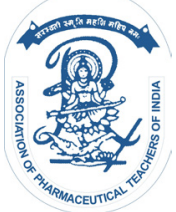

www.ijper.org 
during drying especially primary drying. ${ }^{3,4}$ Wide variety of materials has been used as a cryo and lyoprotectants., Silk fibroin a natural protein obtained from bombyx mori cocoons is also reported as stabilizer ${ }^{7,8}$ but specific reports has not been appeared in any of the literature.

In this research work we have planned to investigate silk fibroin as a stabilizer (cryoprotectant) for thermolabile drug during FD. Silk fibroin itself is an unstable at normal storage temperature and is a challenging task to use it as a cryoprotectant in freeze drying of thermolabile substances.

\section{MATERIALS AND METHODS}

\section{Materials}

Silk fibroin was acquired from sericulture farm, Hupari, India. Tenofovir alafinamide fumarate was obtained as gift sample from Cipla, Patalganga, India. Mannitol was obtained from Molychem, Mumbai, India. Sucrose was obtained from Loba Chemie Pvt. Ltd, Mumbai, India.

\section{Methods}

\section{Extraction and Purification of Fibroin}

Dried Bombyx mori silk cocoons were cut into small pieces. Those pieces are treated with boiling aqueous solution of $0.5 \%$ sodium carbonate for 20 mins with stirring. The whole mass of small pieces was repeatedly washed with distilled water to remove the glue-like sericin protein which are soluble in solution of sodium carbonate and dried in hot air oven. Silk fibroin solution was prepared by dissolving $10 \mathrm{gms}$ of degummed silk in 9.3 $\mathrm{M} \mathrm{LiBr}$ solution at $70^{\circ} \mathrm{C}$ for $2 \frac{1}{2}$ hrs. The fibroin solution was dialyzed in a cellulose membrane based dialysis cassette against distilled water for 3 days to remove, changing water every $6 \mathrm{hrs}$, in order to remove LiBr. After dialysis, silk fibroin solution was centrifuged at $4-10^{\circ} \mathrm{C}$ and $9000 \mathrm{rpm}$ for $20 \mathrm{~min}$. The concentrated solutions were stored at $4^{\circ} \mathrm{C}$ and lyophilized to obtain fibroin powder. ${ }^{9-11}$

\section{Lyophilization}

The fibroin solution was freeze at $-20^{\circ} \mathrm{C}$ for $24 \mathrm{hrs}$ and then lyophilized to obtain Silk fibroin powder. In these pressure $0.016 \mathrm{mbar}$ and temperature $-50^{\circ} \mathrm{C}$ was used. The obtained Silk fibroin powder was then grinded by mortar and pestle to obtain fine powder. ${ }^{12-14}$

\section{Characterization of Silk Fibroin}

\section{Determination of the Percentage Yield of Fibroin}

The percent yield of the silk fibroin was calculated from:
$\%$ Weight loss $=\left[\frac{\mathrm{W}_{0}-\mathrm{W}_{\mathrm{t}}}{\mathrm{W}_{\mathrm{t}}}\right] \times 100$

Where, $\mathrm{W}_{0}$ and $\mathrm{W}_{\mathrm{t}}$ are the weight of the silk fiber samples dissolved and SF recovered, respectively.

\section{Preliminary Chemical Tests}

Separated silk fibroin was subjected to preliminary tests and tests and for identification of presence of different amino acid, protein, etc. Tests like Biuret test, Ninhydrin test, Millons test, Xanthoprotein test and Molisch test were carried out. ${ }^{15,16}$

\section{Melting Point}

Melting point of fibroin was determined by capillary tube method. Fericin filled capillary was placed in the Thiele's tube containing liquid paraffin as heating medium and continued heating till the entire sample was melted.

\section{Solubility Studies}

Solubility of fibroin was carried out by gravimetric method in which $1 \mathrm{~g}$ of SF was dispersed in different solvent like water, ethanol and acetone, chloroform, methanol, $0.1 \mathrm{~N} \mathrm{HCl}$ lithium bromide solution, calcium chloride, magnesium chloride solutions.

\section{Isoelectric $\mathrm{pH}$}

Isoelectric $\mathrm{pH}$ of silk fibroin was determined by using $1 \%$ solution of silk fibroin in water; to this slowly ethanol was added till formation of precipitate in solution takes place, the $\mathrm{pH}$ of the solution which is the isoelectric $\mathrm{pH}$ was noted and reported.

\section{UV Spectra of Fibroin}

The ultra-violet absorption spectra were obtained from UV/VIS spectrometer (Jasco V-630). About $1 \mu \mathrm{g} / \mathrm{ml}$ solution of fibroin was prepared in from extracted aqueous SF solution. By using colorimetric cuvette the sample was scanned from 200-800 nm wavelengths. Then the absorbance maxima were found and wavelength of fibroin was determined.

\section{Furrier Transform Infrared Spectroscopy (FTIR)}

An ATR-FTIR spectra of purified fibroin was recorded using Infrared spectrophotometer (Jasco-V-530 model). About $2 \mathrm{mg}$ of sample was ground thoroughly with $\mathrm{KBr}$; uniformly mixed sample kept in sample holder and spectra was recorded over the wave number $400-4000 \mathrm{~cm}^{-1}$ on spectrophotometer

\section{Differential Scanning Calorimeter Analysis (DSC)}

Thermal behavior of separated fibroin was analyzed by DSC on a Shimadzu differential scanning calorimeter 
(TA instruments, model SDT 2960, USA) equipped with intra cooler and refrigerated cooling system was used to analyze the sample.

\section{Powder X-ray Diffraction Analysis (PXRD)}

PXRD patterns of dry powder of separated fibroin were recorded at room temperature on X-ray diffractometer (Philips analytical XRD, PW 3710) with CuKa radiation $(1.54 \AA)$, at $40 \mathrm{kV}, 40 \mathrm{~mA}$ and passing through a nickel filter. Samples were mounted either on a $25-\mathrm{mm}$ holder made of polymethyl methacrylate and were subjected to $\mathrm{X}$-ray powder diffraction analysis in continuous mode with a step size of $0.01^{\circ}$ and step time of 1 second over an angular range of 3 to $40^{\circ} 2 \theta$. Sample holders were rotated in a plane parallel to their surface at $30 \mathrm{rpm}$ during the measurements.

\section{Preformulation Study}

Preformulation is utilization of biopharmaceutical principles in the determination of physicochemical properties of the chemical substance. It is the first learning phase in the development of dosage form. Following tests were carried in the preformulation studies of the drug as well as other excipients.

\section{Physical Testing}

Physical testing involves testing of properties like color, odor, taste etc. by visual inspection.

Generally it gives the first signal of the deterioration of the substance as that usually results in the change in one of those properties.

\section{Determination of $\left(\lambda_{\max }\right)$ of TAF}

It is the maximum absorption wavelength of drug substance. Methanol and distilled water was selected as the solvent of choice for preparation of calibration curve according to solubility characters of drug. Standard solution of drug was prepared by dissolving $100 \mathrm{mg}$ of drug in (80:20) $\mathrm{mL}$ water and methanol. $5 \mathrm{~mL}$ of solution from the $1^{\text {st }}$ stock solution were diluted into $100 \mathrm{ml}$ dist. water so as to get $50 \mu \mathrm{g} / \mathrm{ml}$ concentration of solution. Different aliquots of 20,40,60,80,100 $\mathrm{g} / \mathrm{ml}$ were prepared. Absorbance of these solutions was measured and plotted against concentration to produce calibration curve.

\section{TAF Identification by IR}

Infra red spectroscopy analysis of TAF and was performed using Fourier Transformation Infrared Spectroscopy [Alpha Brooker FTIR (Tokyo, Japan)]. Its spectra were recorded in the wavelength region between $4000 \mathrm{~cm}^{-1}$ to $400 \mathrm{~cm}^{-1}$.

\section{Differential Canning Colorimetry of TAF}

DSC studies were performed to determine the glass Transition temperature ( $\mathrm{Tg}$ ) of the formulation to allow proper design of the process and to investigate their stability by using a Model 821 DSC (Mettler Toledo).

\section{$X$ ray Diffraction of TAF}

XRD patterns of dry powder of separated pure TAF were recorded at room temperature on $\mathrm{X}$-ray diffractometer (Philips analytical XRD, PW 3710) with CuK $\alpha$ radiation $(1.54 \AA)$, at $40 \mathrm{kV}, 40 \mathrm{~mA}$ and passing through a nickel filter.

\section{Optimization of Excipients}

\section{Fibroin}

The aqueous systems for freeze drying were prepared in series of mixtures containing $25 \mathrm{mg}$ TAF + fibroin. Aliquots of the aqueous solution of TAF were combined with $0.5 \% \mathrm{w} / \mathrm{v}, 0.75 \% \mathrm{w} / \mathrm{v}, 1 \% \mathrm{w} / \mathrm{v}, 1.25 \% \mathrm{w} / \mathrm{v}$, $1.75 \% \mathrm{w} / \mathrm{v}, 2 \% \mathrm{w} / \mathrm{v}$ and $3 \%$ fibroin to produce solutions as given in Table 1 . Accurately measured $5 \mathrm{~mL}$ aliquots of the solutions were filled into clean and labeled vials. The vials were kept for deep freezing at $-25^{\circ} \mathrm{C}$ and lyophilization was carried out. (Temp. $-53^{\circ} \mathrm{C}$, pressure: $0.016 \mathrm{mBar})$. After that the dried samples were further subjected to secondary drying by keeping vials in the vacuum chamber (pressure 0.014) for $1 \mathrm{hr}$.

\section{Mannitol}

The aqueous systems for freeze drying were prepared in series of mixtures containing $25 \mathrm{mg}$ TAF + mannitol. Aliquots of the aqueous solution of TAF and combined with $3 \% \mathrm{w} / \mathrm{v}, 6 \% \mathrm{w} / \mathrm{v}, 9 \% \mathrm{w} / \mathrm{v}$ mannitol to produce solutions as given in Table 2 . Accurately measured $5 \mathrm{~mL}$ aliquots of the solutions were filled into clean and labeled vials. The vials were kept for deep freezing at $-25^{\circ} \mathrm{C}$ and lyophilization was carried out. (Temp. $-53^{\circ} \mathrm{C}$, pressure: $0.016 \mathrm{mBar}$ ). After that the dried samples were further subjected to secondary drying by keeping vials in the vacuum chamber (pressure 0.014 ) for $1 \mathrm{hr}$

\section{Sucrose}

The aqueous systems for freeze drying were prepared in series of mixtures containing $25 \mathrm{mg}$ TAF $+3 \%$ $\mathrm{w} / \mathrm{v}$ fibroin + sucrose. Aliquots of the aqueous solution of TAF and fibroin were combined with $10 \% \mathrm{w} / \mathrm{v}$, $15 \% \mathrm{w} / \mathrm{v}, 20 \% \mathrm{w} / \mathrm{v}$ and $25 \% \mathrm{w} / \mathrm{v}$ sucrose to produce solutions as given in Table 3 . Accurately measured $5 \mathrm{~mL}$ aliquots of the solutions were filled into clean and labeled vials. The vials were kept for deep freezing at $-25^{\circ} \mathrm{C}$ and lyophilization was carried out. (Temp: $-53^{\circ} \mathrm{C}$, pressure: $0.016 \mathrm{mBar}$ ). After that the dried samples were 
further subjected to secondary drying by keeping vials in the vacuum chamber (pressure 0.014) for $1 \mathrm{hr}$.

\section{Evaluation of Freeze Dried Product Cake appearance}

The human eye is extremely sensitive to many changes observed in drug formulations and for this reason visual inspection is a valuable tool in the bag of techniques used to assess stability. For lyophilized formulations, the visual appearance of the lyophilized cake is an important characteristic of the formulation. Collapse or discoloration of the cake could indicate a compromised formulation. ${ }^{17}$ Cake appearance of all lyophilized batches was observed.

\section{Assay}

Drug content in the powder under study was determined using UV visible spectroscopy method.

The drug content in freshly prepared known concentration solution was determined. For the determination of $\%$ drug content working solution were prepared by dissolving $10 \mathrm{mg}$ of powder containing $25 \mathrm{mg}$ of TAF in to water and methanol $(80: 20)$, so as to get solution containing concentration $20 \mu \mathrm{g} / \mathrm{ml}$. Absorption maxima of resulting solution was determined by scanning in the region between 200 to $400 \mathrm{~nm}$. Content of drug in powder was calculated by using equation,

$$
\mathrm{y}=\mathrm{mx}+\mathrm{c}
$$

Where, $\mathrm{y}=$ absorbance, $\mathrm{m}=$ slope and $\mathrm{c}=$ Intercept.

\section{Moisture content}

Moisture content of the dried product was determined by Karl-fisher titrator. The amount of moisture was determined equivalent to the Karl-fisher reagent. A $20 \mathrm{ml}$ of anhydrous methanol was transferred to titration vessel. Accurately weighed sample was added and titration was carried out to the electromagnetic end point. Ten microlitres of water were accurately measured and titrated to the end point. ${ }^{18}$

\section{Characterization of Optimized Batches \\ Furrier Transform Infrared Spectroscopy}

FTIR is an important tool to analyze the purity of the drug. FTIR spectrum shows the fundamental peaks corresponding to the chemical nature of the drug and excipients. FTIR studies were carried out in order to determine any possible interaction among drug and excipients used. IR absorption spectrum was determined by Fourier transform infrared spectrophotometer (Jasco- V-530 model). Spectra were recorded over the wave number $400-4000 \mathrm{~cm}^{-1}$. Infrared spectrums of pure drug and optimized batches were recorded. From the overlay spectrum analysis the compatibility of ingredients in the formulations was found out.

\section{Differential Scanning Colorimetry}

DSC studies were performed to determine the glass transition temperature ( $\mathrm{Tg}$ ) of the formulation to allow proper design of the process and to investigate their stability by using a Model 821 DSC (Mettler Toledo). Samples of $1.5-7 \mathrm{mg}$ were analyzed in crimped, vented aluminum pans under a dry nitrogen purge with an automated liquid nitrogen-cooling accessory. Samples were heated from $25^{\circ} \mathrm{C}$ to $400^{\circ} \mathrm{C}$ with a scanning rate of $10^{\circ} \mathrm{C} / \mathrm{min}$

\section{X-ray Diffraction Studies}

The XRD patterns were recorded on X-ray diffractometer (PW 1729, Philips. Netherlands). Samples were irradiated with monochromatized $\mathrm{Cu}-\mathrm{Ka}$ radiation $\left(1.542 \mathrm{~A}^{\circ}\right)$ and analyzed from 50 to $5002 \theta$. The voltage and current used were $30 \mathrm{kV}$ and $30 \mathrm{~mA}$, respectively. The X-ray diffraction procedure to estimate the degree of crystallinity was based upon the measurement of the total scattering and the scattering from the crystalline region of formulations and pure drug.

\section{Short-term Storage Stability}

Short-term stability testing involves storing the product under various different temperature and pressure conditions for a short period of time. The condition of products is evaluated after the period is over and from the results obtained stability of the sample at those conditions is determined. The optimized batches were subjected to short-term stability studies as per ICH stability testing guidelines for biological. Vials were vacuum-sealed and stored at $2-8^{\circ} \mathrm{C} \mathrm{RH}$ and $40^{\circ} \mathrm{C} / 75 \%$ $\mathrm{RH}$ for 1 month. Stability products were analyzed at specific time interval. The vials were evaluated for product appearance, residual moisture content and drug content. ${ }^{19}$

\section{RESULTS AND DISCUSSION \\ Characterization of Fibroin \\ $\%$ Yield of Silk Fibroin}

Extraction using alkali salt about $89.35 \%$ of Silk fibroin was extracted.

\section{Preliminary Chemical Investigation}

Preliminary chemical investigation of purified fibroin showed the presence of proteins and amino acids. Amino acids like glycine, serine, tyrosine, cysteine, etc. have been reported. 


\section{Melting Point}

Melting point of Silk fibroin as determined by capillary method was found to be in the range of $192-194^{\circ} \mathrm{C}$.

\section{Solubility}

Silk fibroin was found to be insoluble in water, methanol and ethanol. It was soluble in alkaline salt solutions like lithium bromide, magnesium chloride and calcium chloride.

\section{Isoelectric pH}

The isoelectric $\mathrm{pH}$ of Fibroin separated by extraction methods was found to be 4.7. This matches with the finding of literature, who reported isoelectric $\mathrm{pH}$ in the range of 3.6-5.2.

\section{UV Spectra of Fibroin}

In Figure 1 silk fibroin shows showed strong absorption band at around $276 \mathrm{~nm}$ of wavelength. Generally, proteins absorb near-ultraviolet region due to the electron transfer of aromatic amino acid, tryptophan, tyrosine and phenylalanine. On the other hand, histidine absorbs at $210 \mathrm{~nm}$, far-ultraviolet region. Fibroin be expected also the absorption at $280 \mathrm{~nm}$, near ultraviolent region. The observed UV spectra of fibroin shown in Figure 1.

\section{Furrier Transform Infrared Spectroscopy of Fibroin}

As silk protein having amide group in their structure, Table 4 shows the characteristic vibration bands around $1637.22 \mathrm{~cm}^{-1}$ were assigned to the absorption peak of the peptide backbone of amide $\mathrm{I}(\mathrm{C}=\mathrm{O}$ stretching), bands around $1509.87 \mathrm{~cm}^{-1}$ to amide II (N-H bending), the bands around 1232 and $1450 \mathrm{~cm}^{-1}$ to amide III (C-N stretching) and $624.62 \mathrm{~cm}^{-1}$ to amide IV. All these characteristic absorbance peaks indicate the existence of a hydrogen-bonded NH group. The molecular conformation of B. mori silk fibroin is characterized by $\beta$-sheet absorption peaks around 1625, 1508 and $1225 \mathrm{~cm}^{-1}$, random coil conformation absorption peaks at 1690 , 1550 and $1262 \mathrm{~cm}^{-1} .^{20}$

The FTIR spectra of fibroin is shown in overlay Figure 4.

\section{Differential Scanning Colorimetry of Fibroin}

Pure SF shows an endothermic peak related to its thermal degradation at $283^{\circ} \mathrm{C}$. Thermal degradation peaks of $\mathrm{SF}$ at temperatures below $290^{\circ} \mathrm{C}$ are characteristic of amorphous SF (silk I) and are present when SF are not submitted to any kind of physical or chemical treatment to induce its conformation to a more stable structure (silk II). In addition, an endothermic peak at $204.6^{\circ} \mathrm{C}$ and an exothermic peak at $224^{\circ} \mathrm{C}$ were observed. The endothermic peak is attributed to the molecular motion within the $\alpha$-helix crystals and the exothermic peak is attributed to the crystallization during heating from a silk I to a silk II structure. The DSC of fibroin shown in overlay Figure 5.

\section{X-ray Diffraction of Fibroin}

In overlay Figure 6 shows PXRD spectra of fibroin, has showed diffraction peaks which are very low in number and intensity. Fibroin powder found a diffraction peak near $2 \theta=80$ and shoulder peak at near $2 \theta=13.16^{\circ}$, $18.14^{\circ}, 20.52^{\circ}$ and $23.46^{\circ}$. Intensities of these peaks are very low so, it can be considered as less crystalline or can be said to be amorphous in nature. ${ }^{21}$

\section{Preformulation Study}

Preformulation studies involve characterization of physical, chemical and mechanical properties of actives pharmaceutical ingredients and excipients which are used to develop stable, safe and effective dosage form. The preformulation investigations confirm that there are no significant barriers to the compound's development as a marketed drug. Following tests were carried out under preformulation study. Tenofovir alafinamide fumarate is selected as API for further formulation. It is thermo-labile in nature; storage condition of TAF is less than $30^{\circ} \mathrm{C}$. Stability is main issue of TAF, impurities are increased when it stored at room temperature. TAF was selected for the enhancement of its stability at room temperature by using lyophilization method for preparation of formulation.

\section{Physical Testing}

The Tenofovir alafinamide fumarate and excipients were studied for physical evaluation by considering different parameters like color, odor, melting point, taste and solubility. According to IP limits results. The TAF and other excipients mannitol, sucrose is white in colour and having characteristics odor. Melting point was found in range as reported in literature. Solubility of TAF was found to be in methanol. Both sugars are soluble in almost all solvents.

\section{Determination of $\lambda_{\max }$ of TAF}

The graph of concentration vs. absorbance of TAF was found to be linear $(r=0.998)$ in the concentration range of 20 to $100 \mu \mathrm{g} / \mathrm{ml}$ at $261 \mathrm{~nm}$. The TAF obeyed Beer-Lamberts law in the range of $20-100 \mu \mathrm{g} / \mathrm{ml}$. The slope and intercept values obtained in calibration curve of TAF are 1.0241 and 0.01441 . The correlation coefficient was found to be 0.998 . The UV spectra TAF shown in overlay Figure 1. 


\begin{tabular}{|c|c|}
\hline \multicolumn{2}{|c|}{ Table 1: Optimization of fibroin concentration. } \\
\hline Batch Code. & Composition \\
\hline F1 & $0.75 \%$ Fibroin $+25 \mathrm{mg} \mathrm{TAF}$ \\
\hline F2 & $1 \%$ Fibroin $+25 \mathrm{mg}$ TAF \\
\hline F3 & $1.25 \%$ Fibroin $+25 \mathrm{mg} \mathrm{TAF}$ \\
\hline F4 & $1.75 \%$ Fibroin $+25 \mathrm{mg}$ TAF \\
\hline F5 & $2 \%$ Fibroin $+25 \mathrm{mg}$ TAF \\
\hline F6 & $3 \%$ Fibroin $+25 \mathrm{mg}$ TAF \\
\hline
\end{tabular}

Table 2: Optimization of mannitol concentration.

\begin{tabular}{|c|c|}
\hline Batch Code. & Composition \\
\hline M1 & $3 \% \mathrm{w} / \mathrm{v}$ Mannitol + 25 mg TAF \\
\hline M2 & $6 \% \mathrm{w} / \mathrm{v}$ Mannitol + 25 mg TAF \\
\hline M3 & $9 \% \mathrm{w} / \mathrm{v}$ Mannitol $+25 \mathrm{mg}$ TAF \\
\hline DM1 & $3 \% \mathrm{w} / \mathrm{v}$ Fibroin $+6 \%$ Mannitol $+25 \mathrm{mg}$ TAF \\
\hline
\end{tabular}

\section{Table 3: Optimization of sucrose concentration.}

\begin{tabular}{|c|c|}
\hline Batch Code. & Composition \\
\hline S1 & $10 \% w / v$ Sucrose $+3 \% w / v$ Fibroin $+25 \mathrm{mg}$ TAF \\
\hline S2 & $15 \% w / v$ Sucrose $+3 \% w / v$ Fibroin $+25 \mathrm{mg}$ TAF \\
\hline S3 & $20 \% w / v$ Sucrose $+3 \% w / v$ Fibroin $+25 \mathrm{mg}$ TAF \\
\hline S4 & $25 \% w / v$ Sucrose $+3 \% w / v$ Fibroin $25 \mathrm{mg}$ TAF \\
\hline
\end{tabular}

\begin{tabular}{|c|c|c|}
\hline \multicolumn{3}{|c|}{ Table 4: FTIR peaks of Fibroin. } \\
\hline $\begin{array}{c}\text { Sr. } \\
\text { No. }\end{array}$ & Functional group & $\begin{array}{c}\text { Observed peak/ Wave } \\
\text { number }\left(\mathbf{c m}^{-1}\right)\end{array}$ \\
\hline 1 & N-H stretching (secondary) & $3264.58 \mathrm{~cm}^{-1}$ \\
\hline 2 & C=O stretching & $1637.22 \mathrm{~cm}^{-1}$ \\
\hline 3 & C-N Stretching & $1448.94 \mathrm{~cm}^{-1}$ \\
\hline 4 & Amide III & $1232.77 \mathrm{~cm}^{-1}$ \\
\hline 5 & C-H deformation & $624.62 \mathrm{~cm}^{-1}$ \\
\hline 6 & N-H deformation (Amide II) & $1509.87 \mathrm{~cm}^{-1}$ \\
\hline
\end{tabular}

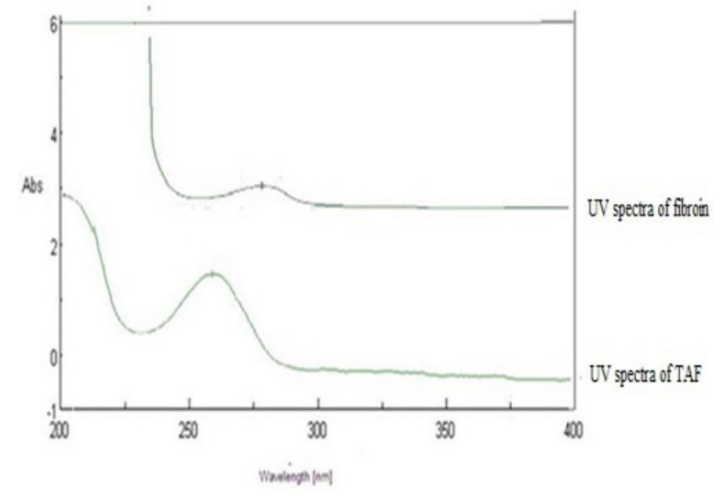

Figure 1: Overlay of UV Spectra of fibroin and TAF.

\begin{tabular}{|c|c|c|}
\hline \multicolumn{3}{|c|}{ Table 5: Observed peak of TAF. } \\
\hline $\begin{array}{c}\text { Functional } \\
\text { group }\end{array}$ & $\begin{array}{c}\text { Standard Peak value } \\
\left(\mathbf{c m}^{-1}\right)\end{array}$ & $\begin{array}{c}\text { Observed Peak } \\
\left.\text { value } \mathbf{( c m}^{-1}\right)\end{array}$ \\
\hline $\begin{array}{c}\text { C=O } \\
\text { stretching }\end{array}$ & $1700-1740$ & 1745.01 \\
\hline $\begin{array}{c}\text { C-N } \\
\text { Stretching }\end{array}$ & $1080-1360$ & 1197.82 \\
\hline $\begin{array}{c}\text { C=C } \\
\text { stretching }\end{array}$ & $1620-1680$ & 1659.90 \\
\hline $\begin{array}{c}\text { C-O } \\
\text { stretching }\end{array}$ & $1000-1300$ & 1300 \\
\hline
\end{tabular}

\begin{tabular}{|c|c|c|c|c|}
\hline $\begin{array}{l}\text { Batch } \\
\text { code. }\end{array}$ & Composition & $\begin{array}{l}\text { Appearance } \\
\text { of Cake }\end{array}$ & $\begin{array}{l}\text { Moisture } \\
\text { content } \\
(\%)\end{array}$ & $\begin{array}{c}\text { Assay } \\
(\%)\end{array}$ \\
\hline F1 & $\begin{array}{c}0.75 \% \mathrm{w} / \mathrm{v} \\
\text { Fibroin }+25 \mathrm{mg} \\
\text { TAF }\end{array}$ & $\begin{array}{c}\text { Poor cake } \\
\text { appearance } \\
\text { with shrinkage }\end{array}$ & 3.3 & 65.3 \\
\hline F2 & $\begin{array}{c}1 \% \text { w/v Fibroin + } \\
25 \mathrm{mg} \mathrm{TAF}\end{array}$ & $\begin{array}{c}\text { Poor cake } \\
\text { appearance } \\
\text { with shrinkage }\end{array}$ & 6.2 & 78.2 \\
\hline F3 & $\begin{array}{c}1.25 \% \mathrm{w} / \mathrm{v} \\
\text { Fibroin }+25 \mathrm{mg} \\
\text { TAF }\end{array}$ & $\begin{array}{l}\text { Poor cake } \\
\text { appearance }\end{array}$ & 4.3 & 69.2 \\
\hline F4 & $\begin{array}{c}1.75 \% \mathrm{w} / \mathrm{v} \\
\text { Fibroin }+25 \mathrm{mg} \\
\text { TAF }\end{array}$ & $\begin{array}{l}\text { Uniform cake } \\
\text { appearance }\end{array}$ & 5.2 & 74.5 \\
\hline F5 & $\begin{array}{c}2 \% \text { w/v Fibroin + } \\
25 \mathrm{mg} \text { TAF }\end{array}$ & $\begin{array}{l}\text { Uniform cake } \\
\text { appearance }\end{array}$ & 4.2 & 78.8 \\
\hline F6 & $\begin{array}{c}3 \% \text { w/v Fibroin + } \\
25 \mathrm{mg} \text { TAF }\end{array}$ & $\begin{array}{l}\text { Uniform cake } \\
\text { appearance }\end{array}$ & 3.1 & 84.3 \\
\hline
\end{tabular}

\section{Furrier Transform Infrared Spectroscopy of TAF}

FTIR spectrum of pure TAF shows characteristic peak at $1745.01,1197.82,1659.90,1300 \mathrm{~cm}^{-1}$ were assigned to the absorption peak of $\mathrm{C}=\mathrm{O}$ stretching, $\mathrm{C}-\mathrm{N}$ Stretching, $\mathrm{C}=\mathrm{C}$ stretching, $\mathrm{C}-\mathrm{O}$ stretching respectively. These peaks ware found to be similar to the peaks that represent basic ketone, aldehyde, aromatic, amine and amide groups. The standard and observed peak values are shown in Table 5. FTIR spectra of pure TAF given in Figure 4.

\section{Differential Scanning Colorimetry of TAF}

Amorphous forms have better aqueous solubility than crystalline forms because the energy required to transfer the molecule into solution from crystal lattice is much greater than that from a non-crystalline (amorphous) solid. The reported melting endothermic peak of pure TAF is at $136.23^{\circ} \mathrm{C}$. The DSC Thermogram of TAF shown in overlay Figure 5. 


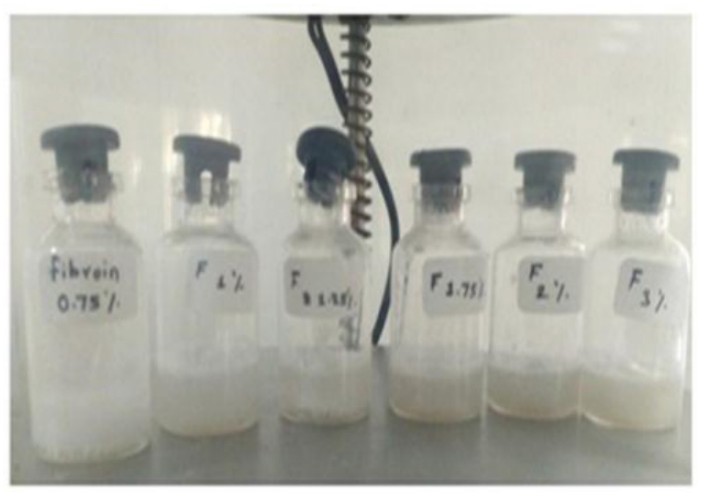

Figure 2: Lyophilization of different concentrations of Fibroin.

\section{X-ray Diffraction of TAF}

The X-ray diffraction of TAF shows sharp peaks which indicate crystallinity which is shown in overlay Figure 6.

\section{Optimization of Excipients}

\section{Fibroin}

During freeze drying there are chances of occurring cryoinjury to product due to low temperature. To overcome this problem cryoprotectants which prevents the product damaging are used. Wide variety of materials has been used as a cryo and lyoprotectants. Silk fibroin a natural protein obtained from bombyx mori cocoons is reported to be used as stabilizer. Thus, we wish to investigate silk fibroin as cryoprotectant in freeze drying processing of model thermolabile drug. For optimization we select the different concentrations of fibroin which shown in Table 1. Lyophilization of various fibroin concentrations are seen in Figure 2.

\section{Mannitol and Sucrose}

Sugars are proven to be excellent bulking agents in case the dose of selected drug is very low. ${ }^{22}$ Hence, in the present study for comparison mannitol and sucrose has been used as a bulking agent mainly due to its high water soluble property. It also co acts as cryoprotectant i.e. it prevents damage to drug molecule from ice crystals. Based on literature review different concentrations of mannitol and sucrose were taken (as shown in Table 2, 3) and evaluated by cake appearance, drug and moisture content. The values obtained from these parameters are shown in next tables.

\section{Optimization and Evaluation of Freeze Dried Batches}

The batches prepared above were checked for appearance and height of cake, moisture content and assay as preliminary testing. This was done to select the batches with the best results that will be evaluated later.

\section{Cake Appearance}

Cake appearance is an important attribute of freezedried products, which may or may not be critical with respect to product quality (i.e., safety and efficacy). Striving for "uniform and elegant" cake appearance may continue to remain an important goal during the design and development of a lyophilized drug product. As some batches of fibroin shows uniform cake appearance and mannitol shows uniform and elegant cake appearance. However, "sometimes" a product with sucrose forms non-ideal or robust cake appearance has no impact on product quality.

\section{Assay}

All lyophilized formulations ware studied for percent drug content. As mannitol is used ideal Cryoprotectant, it showed more drug content as compare to fibroin and sucrose. Batches of fibroin gave better results than sucrose.

Percent TAF content of all batches of fibroin, mannitol and sucrose shown in Table 6, 7 and 8 respectively.

\section{Moisture Content}

Residual moisture content or water content is amount of water present in the material in any form. Various methods are available for moisture content determination like loss on drying, oven drying method, Karl-fischer titration method etc. Moisture analysis of freeze dried products was performed using a Karl Fischer Titrator (Vigo - Matic M.D). By this method moisture content of all batches of fibroin, mannitol and sucrose presented in Table 6, 7 and 8 respectively. This shows that batches containing sucrose concentration having more moisture content than batches of fibroin and mannitol.

On the basis of results obtained from $\%$ drug content, $\%$ moisture content and appearance of cake $3 \% \mathrm{~W} / \mathrm{V}$ Fibroin, $6 \% \mathrm{~W} / \mathrm{V}$ Mannitol and $25 \% \mathrm{~W} / \mathrm{V}$ Sucrose was found to be best concentration and they are selected for further characterization.

Figure 3 shows lyophilized products of optimized batches.

The comparative efficiency of optimized batches shown in Table 9.

\section{Characterization of Optimized Batches Furrier Transform Infrared Spectroscopy}

Figure 4 shows FTIR spectra of fibroin, TAF and optimized batches. The FTIR of optimized batches shows peak near the standard peak value of TAF, so it was confirmed that TAF was successfully incorporated in 


\begin{tabular}{|c|c|c|c|c|}
\hline $\begin{array}{l}\text { Batch } \\
\text { Code. }\end{array}$ & Composition & $\begin{array}{c}\text { Appearance } \\
\text { of Cake }\end{array}$ & $\begin{array}{c}\text { Moisture } \\
\text { content } \\
(\%)\end{array}$ & $\begin{array}{c}\text { Assay } \\
(\%)\end{array}$ \\
\hline M1 & $\begin{array}{c}3 \% \mathrm{w} / \mathrm{v} \\
\text { Mannitol + } 25 \\
\mathrm{mg} \mathrm{TAF}\end{array}$ & $\begin{array}{l}\text { Uniform cake } \\
\text { appearance }\end{array}$ & 2.2 & 88.2 \\
\hline M2 & $\begin{array}{c}6 \% \mathrm{w} / \mathrm{v} \\
\text { Mannitol + } 25 \\
\text { mg TAF }\end{array}$ & $\begin{array}{l}\text { Uniform cake } \\
\text { appearance }\end{array}$ & 1.4 & 93.5 \\
\hline M3 & $\begin{array}{c}9 \% \mathrm{w} / \mathrm{v} \\
\text { Mannitol + } 25 \\
\text { mg TAF }\end{array}$ & $\begin{array}{l}\text { Uniform cake } \\
\text { appearance }\end{array}$ & 2.5 & 90.1 \\
\hline FM1 & $\begin{array}{c}3 \% \text { w/v Fibroin } \\
+6 \% \mathrm{w} / \mathrm{v} \\
\text { Mannitol }+25 \\
\text { mg TAF }\end{array}$ & $\begin{array}{l}\text { Uniform cake } \\
\text { appearance }\end{array}$ & 1.7 & 86.2 \\
\hline
\end{tabular}

\begin{tabular}{|c|c|c|c|c|}
\hline $\begin{array}{l}\text { Batch } \\
\text { Code. }\end{array}$ & Composition & $\begin{array}{c}\text { Appearance } \\
\text { of Cake }\end{array}$ & $\begin{array}{l}\text { Moisture } \\
\text { content } \\
(\%)\end{array}$ & $\begin{array}{c}\text { Assay } \\
(\%)\end{array}$ \\
\hline S1 & $\begin{array}{c}10 \% \mathrm{w} / \mathrm{v} \text { Sucrose } \\
+3 \% \mathrm{w} / \mathrm{v} \text { Fibroin }+ \\
25 \mathrm{mg} \text { TAF }\end{array}$ & $\begin{array}{l}\text { Robust cake } \\
\text { appearance }\end{array}$ & 3.8 & 64.2 \\
\hline S2 & $\begin{array}{c}15 \% \text { w/v Sucrose } \\
+3 \% \text { w/v Fibroin } \\
+25 \mathrm{mg} \text { TAF }\end{array}$ & $\begin{array}{l}\text { Robust cake } \\
\text { appearance }\end{array}$ & 4.2 & 67.2 \\
\hline S3 & $\begin{array}{l}20 \% \text { w/v Sucrose } \\
+3 \% \text { w/v Fibroin } \\
+25 \mathrm{mg} \text { TAF }\end{array}$ & $\begin{array}{l}\text { Robust cake } \\
\text { appearance }\end{array}$ & 5.3 & 70 \\
\hline S4 & $\begin{array}{c}25 \% \text { w/v Sucrose } \\
+3 \% \text { w/v Fibroin } \\
+25 \mathrm{mg} \mathrm{TAF}\end{array}$ & $\begin{array}{l}\text { Robust cake } \\
\text { appearance }\end{array}$ & 4.1 & 73.5 \\
\hline
\end{tabular}

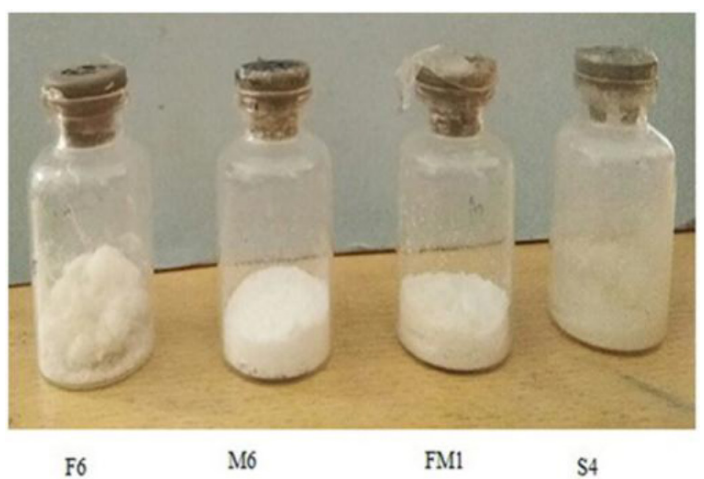

Figure 3: Lyophilized product of optimized batches.

fibroin. Table 10 shows values of major peaks in IR spectrum of TAF and optimized batches.

\begin{tabular}{|c|c|c|c|c|}
\hline \multicolumn{5}{|c|}{ Table 9: Comparative efficiency. } \\
\hline $\begin{array}{c}\text { Batch } \\
\text { Code. }\end{array}$ & Composition & $\begin{array}{c}\text { Appearance } \\
\text { of Cake }\end{array}$ & $\begin{array}{c}\text { Moisture } \\
\text { content } \\
(\%)\end{array}$ & $\begin{array}{c}\text { Assay } \\
(\%)\end{array}$ \\
\hline F6 & $\begin{array}{c}3 \% \mathrm{w} / \mathrm{v} \text { Fibroin }+ \\
25 \mathrm{mg} \text { TAF }\end{array}$ & $\begin{array}{c}\text { Uniform cake } \\
\text { appearance }\end{array}$ & 3.1 & 84.3 \\
\hline M2 & $\begin{array}{c}6 \% \mathrm{w} / \mathrm{v} \text { Mannitol } \\
+25 \mathrm{mg} \text { TAF }\end{array}$ & $\begin{array}{c}\text { Uniform cake } \\
\text { appearance }\end{array}$ & 1.4 & 93.5 \\
\hline FM1 & $\begin{array}{c}3 \% \mathrm{w} / \mathrm{v} \text { Fibroin }+ \\
6 \% \mathrm{w} / \mathrm{v} \text { Mannitol } \\
+25 \mathrm{mg} \text { TAF }\end{array}$ & $\begin{array}{c}\text { Uniform cake } \\
\text { appearance }\end{array}$ & 1.7 & 86.2 \\
\hline S4 & $\begin{array}{c}25 \% \mathrm{w} / \mathrm{v} \text { Sucrose } \\
+3 \% \mathrm{w} / \mathrm{v} \mathrm{Fibroin} \\
+25 \mathrm{mg} \text { TAF }\end{array}$ & $\begin{array}{c}\text { Robust cake } \\
\text { appearance }\end{array}$ & 4.1 & 73.5 \\
\hline
\end{tabular}

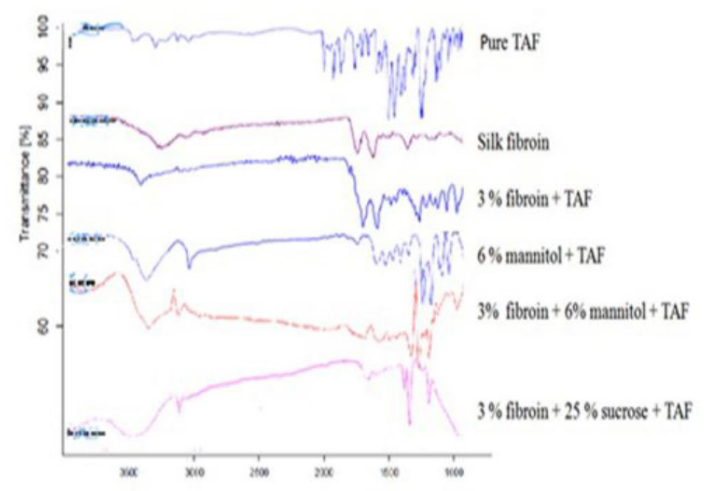

Figure 4: FTIR overlain of TAF, fibroin and formulations.

\section{Differential Scanning Colorimetry}

Differential Scanning Colorimetry (DSC) is frequently used thermal analysis technique that provides detailed information about the physical and energetic properties of substance and mixtures. Understanding the response of drugs and their additives to thermal stresses is an integral part of the development of stable formulations. Single components can exhibit crystallization, solidsolid transitions, glass transitions and polymorphic transitions. These transitions may be endothermic or exothermic. As the temperature increases, an amorphous solid will become less viscous. At some point the molecules may obtain enough freedom of motion to spontaneously arrange themselves into a crystalline form known as the crystallization temperature (Tc). This transition from amorphous solid to crystalline solid is an exothermic process and results in a peak in the DSC signal. DSC overlay of fibroin, TAF and optimized batches shown in Figure 5.

\section{X-ray Diffraction}

The XRPD pattern of TAF confirmed the structure and absolute configuration, which had been previously determined by chemical studies. The XRPD pattern of 


\begin{tabular}{|c|c|c|c|c|c|}
\hline \multicolumn{6}{|c|}{ Table 10: Values of major peaks in IR spectrum of TAF and optimized batches. } \\
\hline Functional group & $\begin{array}{c}\text { Observed Peak } \\
\text { value (cm }{ }^{-1)}\end{array}$ & 3\% Fibroin + 25 mg TAF & 6\% Mannitol+ 25 mg TAF & $\begin{array}{c}\mathbf{3 \%} \text { Fibroin + } \\
\mathbf{6 \%} \text { Mannitol + } \\
\mathbf{2 5} \mathbf{~ m g ~ T A F}\end{array}$ & $\begin{array}{c}\mathbf{3} \% \text { Fibroin + } \\
\mathbf{2 5 \%} \text { sucrose + } \\
\mathbf{2 5} \mathbf{~ m g ~ T A F ~}\end{array}$ \\
\hline C=O stretching & 1745.01 & 1621.224 & 1894.56 & 1831.74 & 1786.85 \\
\hline C-N Stretching & 1197.82 & 1150.099 & 1194.64 & 1194.19 & 1123.30 \\
\hline C=C stretching & 1659.52 & 1621.224 & 1590.22 & 1457.32 & 1527.08 \\
\hline O-H stretching & 796.52 & 768.543 & 715.41 & 711.80 & 858.90 \\
\hline C-O stretching & 1300 & 920.735 & 1318.76 & 1300.19 & 1234.53 \\
\hline
\end{tabular}

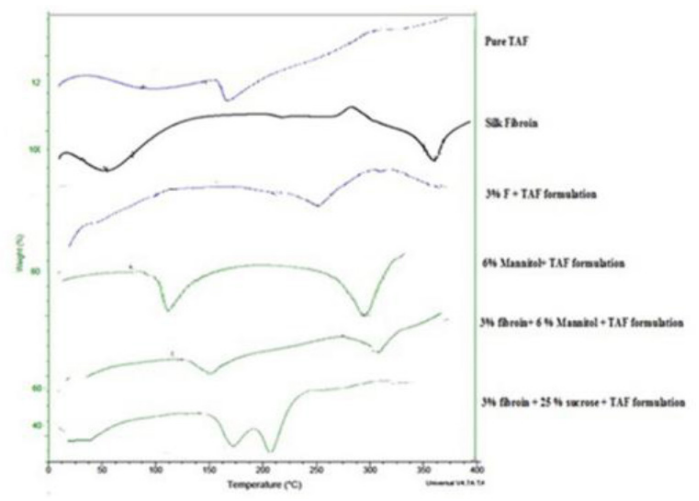

Figure 5: DSC overlain of TAF, fibroin and formulations.

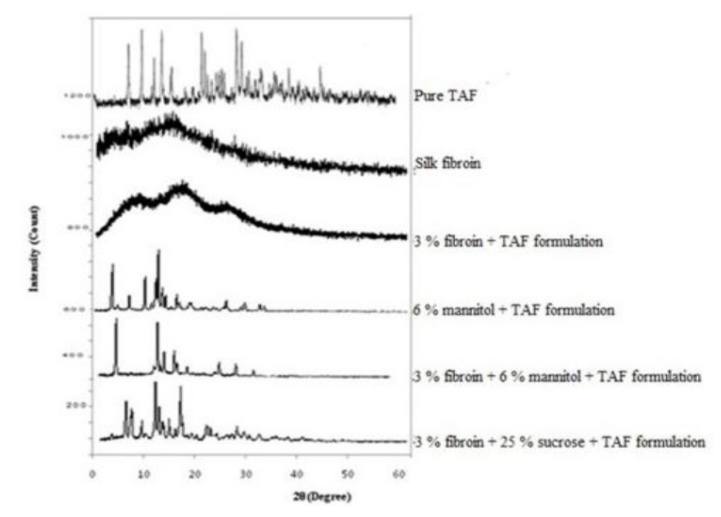

Figure 6: XRD overlain of TAF, fibroin and formulations.

TAF formulation used in this study showed sharp peaks that were characteristic of crystalline TAF. This finding was confirmed by the presence of a melting point peak observed in DSC studies at $136.8^{\circ} \mathrm{C}$. The overlay of $x$-ray diffraction patterns of fibroin, TAF and optimized batches are shown in Figure 6.

X-ray diffraction analyzes the physical state of any mixture. It gives idea about how much crystallinity is present in a given mixture. The crystallinity index should be minimum after keeping formulation for long time. Studies have been reported to quantify the effect of additives on physical state of sugars during lyophilization and spray drying. ${ }^{23}$ Crystallization of excipients during dehydration is an important factor in the stability of product. The changes in amorphous or crystalline nature of formulations significantly affect performance and stability of protein pharmaceuticals.

\section{Short Term Storage Stability}

The samples were stored at $25^{\circ} \mathrm{C} / 60 \% \mathrm{RH}$ and $40^{\circ} \mathrm{C} / 75 \% \mathrm{RH}$ up to one month. After one month, the FD formulations were analyzed again for drug content and moisture content. No significant changes were observed after one month in drug and moisture content. Stability data of optimized batches showed in Table 11.

\section{CONCLUSION}

Stability issue of heat sensitive pharmaceuticals is a major problem which can be solved by number of methods and one amongst them is use of natural material Silk fibroin. In the present research work an attempt is made to investigate use of silk fibroin as a stabilizer for model thermolabile drug Tenofovir Alafinamide Fumarate (TAF).

Based upon literature reviewed various formulations were designed and trials were taken silk fibroin as a stabilizer over 0.75 to $3 \% \mathrm{w} / \mathrm{v}$. A formulation with $3: 1$ fibroin: TAF ratio was found to be best. Using various features such $\%$ drug content, $\%$ residual moisture and appearance of lyophilizate and investigation by modern techniques such FT-IR, XRD, DSC these formulations were tested to confirm suitability of formulation components. Initially for achieving desirable product features the fibroin concentration was varied and then optimized. The optimized concentration of fibroin was compared with commonly used cryoprotectants; mannitol and sucrose. These cryoprotectants alone did not provide sufficient protection to drug during lyophilization. Thus they were composed with fibroin and again optimized for the desired features. The efficiency of fibroin as cryoprotectant was compared using product features. It was observed that product features and stabilization efficiency of fibroin was lower than mannitol where as it was better than sucrose. The probable mechanism involved in the stabilization by silk fibroin could be a 


\section{Table 11: Stability data of optimized batches.}

\begin{tabular}{|c|c|c|}
\hline Batches & $\begin{array}{c}\text { Drug } \\
\text { content (\%) }\end{array}$ & $\begin{array}{c}\text { Moisture } \\
\text { content (\%) }\end{array}$ \\
\hline 3\% fibroin + TAF & 80.3 & 3.3 \\
\hline 6\% mannitol + TAF & 92.2 & 1.4 \\
\hline $3 \%$ fibroin + 6 \% mannitol + TAF & 84.6 & 1.8 \\
\hline 3\% fibroin + 25\% sucrose + TAF & 66.2 & 5.4 \\
\hline
\end{tabular}

water replacement hypothesis. The hydrogen bonding between TAF and the fibroin is stronger than between these sugars and TAF due to more number of $-\mathrm{OH}$ groups in fibroin. The results of stability study indicated that fibroin products were stable over the period of a month. Thus, it can be concluded that silk fibroin could be successfully used to stabilize theromo sensitive therapeutics. In comparison, fibroin seems to stabilize labile drugs efficiently by reducing production cost with low toxicity risk. Thus, it can be concluded that silk fibroin is a promising excipient to be used as a stabilizer because of its cryopreserving properties.

\section{ACKNOWLEDGEMENT}

Author would like to thank to Dr. H. N. More, Principal of Bharati Vidyapeeth College of Pharmacy, Kolhapur for providing facilities to carry out our research work. I also take this privilege and pleasure to acknowledge the contributions of many individuals who have been inspirational and supportive throughout my work undertaken.

\section{ABBREVIATIONS}

TAF: Tenofovir Alafinamide Fumarate; SF: Silk Fibroin; API: Active Pharmaceutical Ingredients; IP: Indian Pharmacopeia; ICH: International Conference of Harmonization; mL: Milliter; mg: Milligram; $\mu \mathrm{g}$ : Microgram; UV: Ultra-Violet; FTIR: Fourier Transform Infrared Spectroscopy; DSC: Differential Scanning Colorimetry; XRD: X- Ray Diffractometer.

\section{CONFLICT OF INTEREST}

The authors declare no conflict of interest.

\section{REFERENCES}

1. Kumar S, Gautam N, Minhaj A, Kapoor S. Devolopment and optimization of lyophilization cycle. World J Pharm Res. 2015; 4(2):1053-62.

2. Baheti A, Kumar L, Bansal AK. Excipients used in lyophilization of small molecules. J Excipients and Food Chem. 2010; 1(1):41-54.

3. Milton N, Pikal MJ, Roy NL, Nail SL. Evaluation of monometric temperature as a method of monitoring product temperature during lyophilization. PDA J Pharm Sci Technol. 1997; 51(1):7-16.

4. Shivanand A, Mukhopadhayaya S. A review on Lyophilization: A technique to improve stability of hygroscopic, thermolabile substances. Pharma Tutor. 2017; 5(11):28-39.

5. Joshi AJ, et al. A Review and Application of Cryoprotectant: The Science of Cryonics. Pharma Tutor. 2016; 4(1):12-8.

6. Hubalek Z. Protectants used in the cryopreservation of microorganisms. Cryobiology. 2003; 46(3):205-29.

7. Joseph B, Justin RS. Therapeutic applications and properties of silk proteins from Bombyx mori. Front Life Sci. 2012; 6(3-4):55-60.

8. Kaplan D, Adams WW, Farmer B, Viney C. Silk Polymers: Materials Science and Biotechnolog. 1994; 10-11.

9. Wray LS, et al. Effect of processing on silk based biomaterial: Reproducibility and biocompatibility. J Biomed Master Res B Appl Biometer. 2011; 99(1):89101.

10. Leland FG, Hariris M. Combination of silk fibroin with acid and with base. National Bureau of Standards. 1941; 26:71-9.

11. Lu Q, et al. Stabilization and release of enzymes from silk films. Macromol Biosci. 2010; 10(4):359-68.

12. Bhatnagar B, Bogner R, Pikal M. Protein stability during freezing: separation of stresses and mechanisms of protein stabilization. Pharm Dev Technol. 2007; 12(5):505-23.

13. Sablani S, et al. Influence of shelf temperature on pore formation in garlic during freeze-drying. J Food Eng. 2006; 80(1):68-79.

14. Lv $Q$, Feng $Q$. Preparation of 3-D regenerated fibroin scaffolds with freeze drying method and freeze drying/foaming technique. J Mater Sci Mater Med. 2006; 17(12):1349-56.

15. Altman $\mathrm{GH}$, et al. Silk-based biomaterials. Biomaterials. 2003; 24(3):401-16.

16. Leal-Egana A, Scheibel T. Silk-based materials for biomedical applications. Biotechnol Appl Biochem. 2010; 55(3):155-67.

17. Patel SM, et al. Lyophilized drug cake appearance. J Pharm Sci. 2017; 106(7):1706-21

18. Leu-Fen $\mathrm{H}$, Richard B. Moisture matters in lyophilized drug product. BioPharm International. 2012; 25(10):1020.

19. Sandhyarani G, Ramesh A. Development and evolution of lyophilized product of Apo-acetozolamide. IOSR J Pharm. 2016; 2(9):48-63.

20. Edwin $\mathrm{K}$, et al. FTIR and WAXD study of regenerated silk fibroin. Advance Material Research. 2013; 677:211-5.

21. Hao $Z$, et al. Preparation and characterization of silk fibroin as a biomaterial with potential for drug delivery. J Transl Med. 2012; 10(1):117.

22. Hajare A, More N. Effect of sugar additives on stability of doxorubicin hydrochloride during vacuum foam drying and storage. J Pharm Sci. 2011; 6(2):43-56.

23. Zhou J, Wang $\mathrm{H}$. The physical meaning of 5 basic parameters for an $\mathrm{X}$ ray diffraction peak and their applications. Chinese Journal of Geochemistry. 2003; 22(1):38-44.

Cite this article: Mirajkar PG, Hajare AA. Screening of Silk Fibroin as a Stabilizer for Freeze Drying of Thermolabile Drug. Indian J of Pharmaceutical Education and Research. 2019;53(2S):s193-s203. 


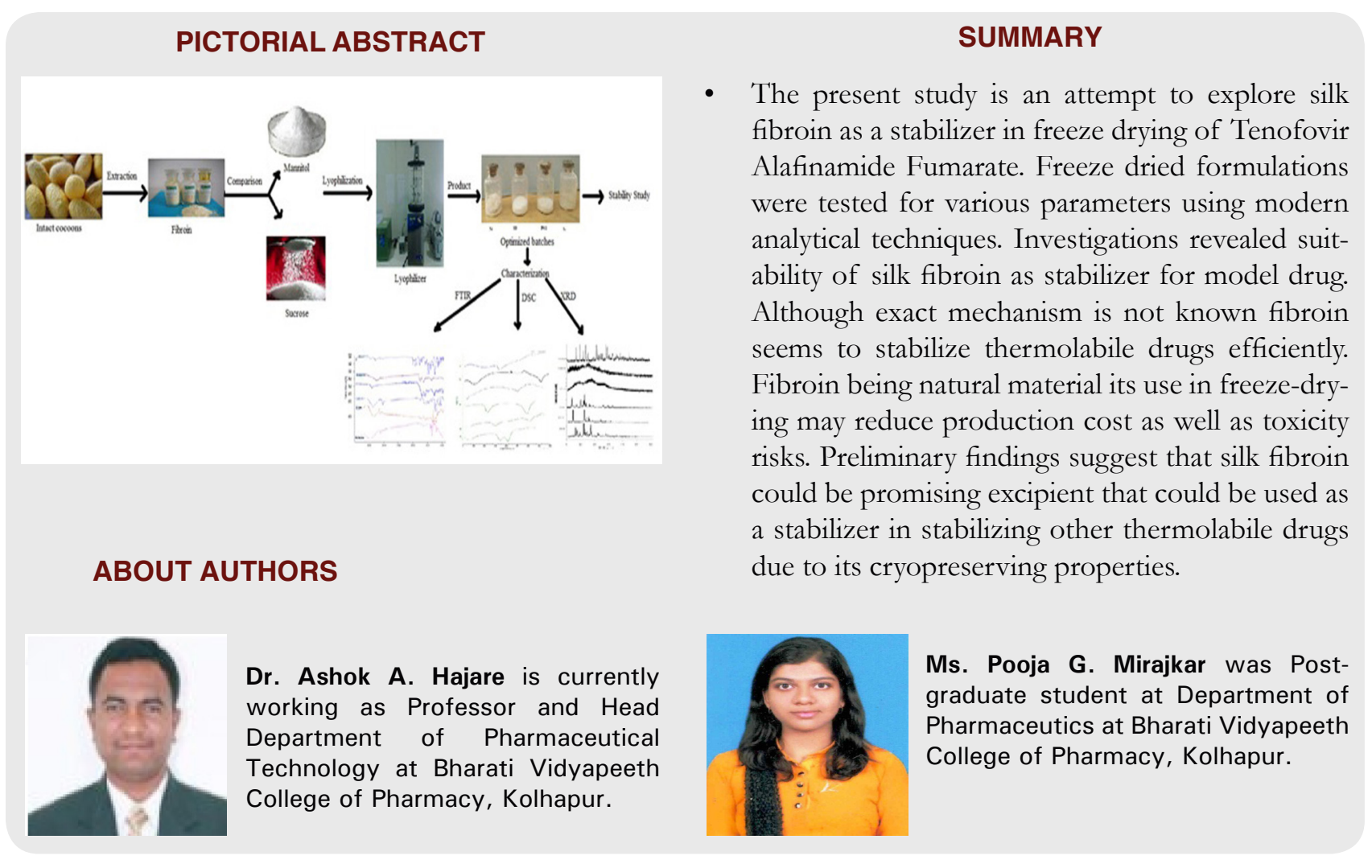

